\title{
Transcendence and immanence into or onto creative pluralism in South Africa
}

\begin{tabular}{|c|c|}
\hline $\begin{array}{l}\text { Author: } \\
\text { Johan A. van R }\end{array}$ & ooyen $^{1}$ (1) \\
\hline $\begin{array}{l}\text { Affiliation: } \\
{ }^{1} \text { Department } \\
\text { and Historical } \\
\text { Faculty of The } \\
\text { Religion, Univ } \\
\text { Pretoria, Pretc } \\
\text { South Africa }\end{array}$ & $\begin{array}{l}\text { f Systematic } \\
\text { Theology, } \\
\text { ology and } \\
\text { ersity of } \\
\text { ria, }\end{array}$ \\
\hline $\begin{array}{l}\text { Research Proje } \\
\text { Project Leade } \\
\text { Project Numb }\end{array}$ & $\begin{array}{l}\text { ct Registration: } \\
\text { : D.P. Veldsman } \\
\text { er: } 01224719\end{array}$ \\
\hline $\begin{array}{l}\text { Description: } \\
\text { This research i } \\
\text { project, 'Religi } \\
\text { from an evolu } \\
\text { perspective', c } \\
\text { Dr Danie Velds } \\
\text { Department o } \\
\text { and Historical } \\
\text { Faculty of The } \\
\text { Religion, Unive } \\
\text { Pretoria. }\end{array}$ & $\begin{array}{l}\text { s part of the } \\
\text { ous Experience } \\
\text { ionary } \\
\text { irected by Prof. } \\
\text { man, } \\
\text { Systematic } \\
\text { Theology, } \\
\text { logy and } \\
\text { ersity of }\end{array}$ \\
\hline $\begin{array}{l}\text { Correspondin } \\
\text { Johan van Roo } \\
\text { roojresearch@ }\end{array}$ & $\begin{array}{l}\text { author: } \\
\text { yen, } \\
\text { gmail.com }\end{array}$ \\
\hline $\begin{array}{l}\text { Dates: } \\
\text { Received: } 27 \mathrm{C} \\
\text { Accepted: } 17 \\
\text { Published: } 23\end{array}$ & $\begin{array}{l}\text { ct. } 2020 \\
\text { eb. } 2021 \\
\text { Apr. } 2021\end{array}$ \\
\hline $\begin{array}{l}\text { How to cite th } \\
\text { Van Rooyen, J. } \\
\text { 'Transcenden } \\
\text { immanence in } \\
\text { creative plural } \\
\text { South Africa', } \\
\text { Studies/Theolc c } \\
77(4) \text {, a6371. } \\
\text { org/10.4102/h }\end{array}$ & $\begin{array}{l}\text { is article: } \\
\text { A., 2021, } \\
\text { e and } \\
\text { to or onto } \\
\text { ism in } \\
\text { tTS Teologiese } \\
\text { gical Studies } \\
\text { https://doi. } \\
\text { ts.v77i4.6371 }\end{array}$ \\
\hline $\begin{array}{l}\text { Copyright: } \\
\text { (c) 2021. The A } \\
\text { Licensee: AOS } \\
\text { is licensed und } \\
\text { Creative Comn } \\
\text { Attribution Lic }\end{array}$ & $\begin{array}{l}\text { uthors. } \\
\text { S. This work } \\
\text { ler the } \\
\text { nons } \\
\text { ense. }\end{array}$ \\
\hline Read online: & \\
\hline 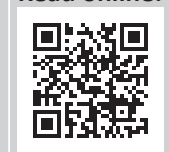 & $\begin{array}{l}\text { Scan this QR } \\
\text { code with your } \\
\text { smart phone or } \\
\text { mobile device } \\
\text { to read online. }\end{array}$ \\
\hline
\end{tabular}

Two philosophical tools are used in this article, namely (1) that of philosophical-pluralism and (2) transcendent pluralism as a kind of glue to enhance our examining of creative pluralism. There is a diversity implant in positive modus of understanding this pluralistic pristine of creative pluralism within transcendence modus. To help facilitate this pluralistic pristine, the author makes use of three constructivist paradigms that are distinguished and used, namely (1) exogenous constructivism (rooted in a mechanistic metaphor) emphasising the reconstruction of structures preformed in the environment; (2) endogenous constructivism (rooted in an organismic metaphor) emphasising the coordination of previous organismic structures and (3) dialectical constructivism (rooted in a contextualistic metaphor) emphasising the construction of new structures out of organism and environmental interaction.

Contribution: The aim of this article is to present a coherent metatheory by specifying the boundary conditions in which each root metaphor (constructive pluralism) best applies. These above-mentioned versions of pluralism as tools are a reminiscence and a jubilee of the efforts made by sapiens through diversity onto or into pluralism to enable the religious hamlet to think and share. This pluralistic approach of orientation, I hope, will empower sapiens in their respective hamlets to define, articulate and designate to enhance their own epistemological and ontological vantage points wherefrom their individual, coherent and contextual ways of thinking, acting and projecting their lives in a positive modus by emphasising the reconstructions of their performance in their environment.

Keywords: epistemology; natural science; transcendental; exogenous constructivism; endogenous constructivism; dialectical constructivism.

\section{Introduction}

It is suggested that more general metatheories integrating exogenous, endogenous and dialectical aspects of the construction of knowledge can and should be formulated. Such formulations would not attempt an impossible synthesis of these root metaphors, but rather integrate them in a coherent metatheory by specifying the boundary conditions in which each root metaphor best applies and then applies the transcendent construction to help the synthesis, as an example to name only one, the Jean Piaget's theory of cognitive development. However, as the author is a citizen of South Africa, a Christian theologian and member of the Nederduits Reformed Church of South Africa (although defiantly not in the bosom of it), and therefore a born white South African in Africa, the departing monument of this article originates from within a South African context.

\section{From diversity to pluralism, ${ }^{1}$ South Africa}

All South Africa's diversity never determines a subjoin to conflation (pluralism). 'Pluralism' and 'diversity' are frequently pre-owned as if they were identical. To illuminate this point, I can speak of diversity as splendid and colourful, and for others, it could mean a threat, a danger, and because of different hermeneutical implications it could have on sapiens consciousness, diversity cannot qualify as pluralism.

Diversity is the promise that originates in a prevalent hamlet ${ }^{2}$ that is pluralism, as it can be or maybe not. It all depends on the reader's epistemological points of view. In this article, a 1.Please take note that in the context of this article, the terms pluralism and dissimilarities are used interchangeable. The reason for this
is that it is better for me to use these terms in different albeit same meaning of the terms from time to time in this article.

2.An expressive word alike 'hamlet(s)', in this context, is a substitution for the term 'society'. The reason for this substitution has to do with the term 'society', that is to my mind a too laden (heavy) term in the relevant present-day contemporary communities, especially in South Africa, and therefore, the term 'hamlet' is used in the context of this article.

Note: Special Collection: Theology, Economy and Environment: Social, Cultural and Biotic Influences on Religious Communities, subedited by Jerry Pillay (University of Pretoria). 
hamlet(s) existence agreement (or sapiens existence analogy or rather sapiens existence of being) is in one or the other way a creation within the framework of sapiens hamlets. According to me, this can be a positive element of being diverse and then pluralistic in these endeavours. This will be explained later in this article as, for example, on the same street in Mbombela in Mpumalanga, South Africa (where I domicile), there exists a Greek orthodox church, a Thailand's Buddhist temple, a Muslim community centre, a South African Zionist church, Dutch Reformed church as well as a Hindu temple.

In South Africa, we speak 11 official languages such as Southern Sotho, Pedi/Northern Sotho, Tswana, Swati, Ndebele, Xhosa, Zulu, Afrikaans, English, Venda and Tsonga. There are also a few non-official languages such as the San or Bushman language. It can surely qualify as diversity; however, beyond some promise or dependence between the diverse orders, it does not automatically allure a case for pluralism. Pluralism, to me, is only one of the probable means of agreeing to diversity. Somebody can sense danger by diversity and sense a kind of warlike to it. Some might peek or glance to promote the time, as an example, that all these differences slide into a view that is predominately Christian lifestyle. Someone, like me, who welcomes diversity, originates a viable pluralism that creates a desire when talking to humans of diverse religions and lifestyles in the development of an ordinary hamlet. Pluralism is therefore not at all disposed, however, realisation of it is challenging work.

Within an antiquity point of view, the premise of omission, adaptation and pluralism brings to mind three diverse means of how South Africans have near this extension of lifestyles and reverent diversity. The expansionist's conclusion to the boisterous incursion of different lifestyles and reverent diversity that intimidate the pure essence of South African hamlets was to open South African borders for even more, so-called aliens, whether Nigerians, Muslims, Asians or even the Chinese.

Conformists, alike these who anticipate a South Africa as a dwindle-crucible solicited everyone outside South Africa's borders, and is still doing so, more aliens to adhere to this call, but to abandon their divergences and idiosyncrasies posteriorities behind as prompt as probable. The directive is: besiege alike us, and yield to an essentially South African 21st-century post-colonialism, where there is enough for everyone. For African pluralists, like Nelson Mandela and a couple of his old guard, it boils down to: besiege as you are, with all your divergences and idiosyncrasies, warrant only to be a sapiens with its 'human rights', and all will be okay! Be what you are, furnish in your unique way to the sinfonietta of South African civilisation.

In contrast to the Americas today, South Africa's reverent and diverse ways of life reverberates those calls of antiquity. However, South Africa's new reverent diversity, post-1994, has generated blemishes, with fractures that record recondite chunks and separation. Although I myself do not regard these as negative as with everything else in life a fresh start means errors have to be made yet learning from them is crucial. But most do not! As an example, the xenophobia outbreaks of violence were between 2000 and March 2008, at least 67 people died in that were identified as xenophobic attacks, in and around South African hamlets. As versed by alien Hindu, Buddhist, Sikh or Muslim hamlets, categories and predisposition have appropriated botchy and anew conformations.

Today, as in every era, South Africans are trying to make sense of this anew meaning of a multi-religious as well as multi-cultural South Africa. How do we relate to one another, when we include 11 official languages, work, play and live as sapiens Christians, Muslims, Hindus, Buddhists and indigenous African religions and cultures? Thus, what exactly is diversity into or onto pluralism?

\section{What is diversity and pluralism in the South African context?}

Firstly, diversity is not the exact fact or facet of pluralism alone; still, it is an operative promise with that dissimilarities. Sapiens can be an onlooker of these dissimilarities, solemnise these dissimilarities, as these platitudes are verbalised or in contradiction it might be frowned upon and threatening. Notwithstanding this, both need concurrence and promise. Dissimilarities might be intended with the creation of subcultures of clergy and the vital of these dissimilarities is one of togetherness and a visa versa gridlock. As an example, the music of white man-Zulu Johnny Clegg, ${ }^{3}$ who succumbed to cancer in 2019.

Secondly, dissimilarities are increased as the sheer sufferance of differences. It requires knowledge of these differences and although tolerance ${ }^{4}$ is important, it can be a fallacious probity by itself, somewhat obscuring the road towards promise. Sufferance does not obligate sapiens to understand all or for that matter, everything about one another. Thus, it can accommodate all the categories and half-truths we require to engage our neighbours, as sufferance is absolutely substantial. Yet, it does little to dislodge the unintelligence of others and it is therefore a too flimsy footing for a hamlet as religious dissimilar and labyrinthine as South Africa.

Thirdly, pluralism is not candidly relativism (the doctrine that knowledge, truth and morality exist in relation to culture, society or historical context, and are not absolute), and

3.Jonathan (Johnny) Paul Clegg (07 June 1953 - 16 july 2019) was a South African musician, singer-songwriter, dancer, anthropologist and anti-apartheid activist. Some of his work was in musicology focused on the music of indigenous South Some of his work was in musicology focused on the music of indigenous South African peoples. His band Juluka began as a duo with Sipho Mchunu and was the The pair performed and recorded, later with an expanded line-up.

4.Please take note that in the context of this article, the terms tolerance and severance are used interchangeable. The reason for this is that it is better for me to use these are used interchangeable. The reason for this is that it is better for me to use these
terms in different albeit same meaningful contexts; however, for me, it resonates better from time to time as interchangeable in this article. 
therefore, it is an actual for divergent reverend commitments. Sapiens are circumspect of the lingo of these dissimilarities and thus demand that dramatically minimalising sapiens reverend beliefs by conceding to other sapiens belief variously, and that it is okay and not a threat to their own. Some sapiens erroneously think that a pluralist point of view presumes that there are not any means of dissimilarities amidst a sundry reverend way of life and its utilities, so they, in fact, encounter the dissimilarity hamlet as one of the most authentic commitments of absolute dissimilarities. Pluralism does not even obligate abandoning of the individuality of a sapiens way of life or believes to attain the exhausted-simpledenominator. ${ }^{5}$ In the civic correspondence of a dissimilarity hamlet, a promise is not reduced but appealed to. Sapiens of every reverend or of none at all could be what they are, with all their individuality, whilst appealing amongst the development of a public hamlet. Therefore, it is important that pluralism be regarded as an evolving process in creating a hamlet through fault-finding with a self-captious argument(s) amongst each other, accepting, comparatively concealing sapiens profound dissimilarities.

Fourthly, dissimilarities in South Africa are ambiguously located on the simplistic guidance of the constitution, ${ }^{6}$ and its vigorous confrontation in pluralistic hamlets is never postulated on consummate accord(s) on fields of compunction and belief, rather, on according to the commodity far more beneficial: the kinship of recurring discourses. E Pluribus Unum (out of many, one) resonates in sapiens minds, a simplistic sense of public 'we', however, not at all just one reverend, one belief, or one apprehension as Unum does not contemplate conformity. Feasible, for me, the almost best simplistic glue sapiens have of various reverends are their reciprocal engagements to a hamlet that are fixed on the contemptible give and take of public discourses through the excepted table.

Fifthly, dissimilarities acquire the sustenance of productive conversions to unveil both simplistic interpretations and unique dissimilarities. Not all at the table will concur with one another. The development and evolution of the debate will unavoidably unveil spheres of disagreements and dissimilarities. However, to me, it is important that pluralism does at least want all role players, and in this case, religious sapiens and deeply cultural sapiens to be at the table, albeit with sapiens different faiths. Ascertaining the position of these tables in South Africa and emboldening a spirit

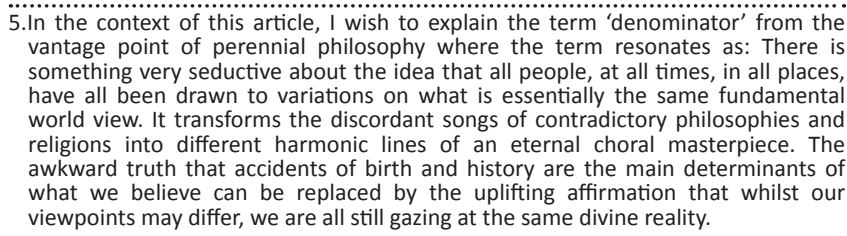
5. In the context of this article, I wish to explain the term 'denominator' from the
vantage point of perennial philosophy where the term resonates as: There is something very seductive about the idea that all people, at all times, in all places, have all been drawn to variations on what is essentially the same fundamental world view. It transforms the discordant songs of contradictory philosophies and religions into different harmonic lines of an eternal choral masterpiece. The awkward truth that accidents of birth and history are the main determinants of what we believe can be replaced by the uplifting affirmation that whilst our viewpoints may differ, we are all still gazing at the same divine reality.

6.In the context of this article, the 'Constitution of South Africa' can be understood as the supreme law of the Republic of South Africa. It provides the legal foundation for the existence of the republic, as it sets out the rights and duties of its citizen for the existence of the republic, as it sets out the rights and duties of its citizen and defines the country's fifth, was drawn up by the Parliament elected in 1994 in the South African general election, 1994. It was promulgated by President Nelson Mandela on 18 December 1996 and came into effect on 04 February 1997, replacing the Interim Constitution of 1993. favourable for engaging in discourses are mortally paramount regarding the prospering of a public hamlet.

Therefore, you might immediately ask: where are these 'tables', where sapiens of all lifestyles and faiths meet in a South African hamlet? It is experienced in sapiens hamlet neighbourhoods, pre-tertiary institutions, universities, legislators and justice delimiting counsels, as well as devising denominations of juncture recommendations and partnerships, reverendships and institutions for the sick. In every one of these areas of sapiens life, South Africans are now facing new questions, new challenges and new tensions in allocating a higher convoluted sense of who South Africans are supposed to be at this time of our history. Specifically, one which new introduction towards dissimilarities is easy to recognise, and for some sapiens, most uncongenial and dubious is the church where Christianity is practised, the Christian church. With no ambiguous question, the belated 20th and initial 21st centuries saw a resurgence of a powerful segregated ecclesiastical Christianity, customarily connected to a jingoist passion in attacking other way of life as antiSouth African. In the same breath, the imaginative and creative interpretations in ancient hamlets are pluralistic related to their ritual interpretation that is modelled on the system and structure of the cosmogonic myths. ${ }^{7}$

The interpretation may also lead to pluralism, as there are many types of pluralisms. Yet, notwithstanding this, this article is earmarked for philosophical-epistemological sapiens religious views as well as those who accommodate cosmic pluralism as diverse tools for sapiens to use in their creation of significant benchmarks in their own time, sublime precision, to mention one example, their technological creations or designs.

There are plenty of references mentioned today, in the media, especially in scientific articles, for example, Nature and Science, where the cosmogonic myths place Homo sapiens in a privileged time and space, for example: 'that the anticipation that the symbolic and empirical names were given to the fauna and flora and the topography, were part of sapiens orientation of themselves' (Long 2016:2). The ensuing emergent processes of language within pluralistic contexts in a sapiens hamlet can be regarded as an extension of the language tool of the cosmogonic myth.

This now brings me to the three constructivisms as follows: (1) exogenous constructivism (rooted in a mechanistic metaphor) emphasising the reconstruction of structures preformed in the environment, (2) endogenous constructivism (rooted in an organismic metaphor) emphasising the coordination of previous organismic structures and (3) dialectical constructivism (rooted in a contextualistic metaphor) emphasising the construction of new structures out of organism and environment interaction. Therefore, how can these constructivisms that are immanent into or onto transcendence help us to transcend it into or onto one tool of 7.For a more detailed elucidation, see Long (2016), Van Rooyen (2020). 
creating a creative pluralism that works, here in South Africa today? Therefore, I start with the first construction, namely exogenous constructionism.

\section{Exogenous constructionism}

Exogenous constructivism is a constructivist perspective that assumes that learning occurs as a result of an individual engaging in cognitive processes that relate their prior knowledge to experiences. This means that the learning of something itself eventuates from a direct result of a sapien that is enticed into or onto their own cognitive processes. ${ }^{8}$ Therefore, albeit that this construction is immanent, it has to follow the root of a transcendental character. 'The situatedness of transcendence, or at least our experience thereof, is posited within human cognition - within the mind with its respective ability (Fähigkeit)' (Van Rooyen 2018:2). How then can this help us in South Africa today to enhance our ability as sapiens citizens:

Within a post-modern South Africa with our increasing modernistic convictions, there is a growing awareness that we live in a world of interpretations. In a broader interdisciplinary sense, there is an acknowledgement that organisms like sapiens managed to understand and use their experiences as $\operatorname{coded}^{9}$ : evolutionary biological, epistemological as well as ontological. (p. 2)

This happened over a prolonged evolutionary time (and space), and this made it possible for species, and in this context sapiens with their pluralistic interpretations, to use sapiens respective experiences for their own benefit. As an example, an innate expectation (intuitive awareness) can be used repeatedly in this exogenous construction to enhance pluralism's tools, as such expectations are based on the process of accumulation of that specific exogenous construction. This innate expectation, seen here as a transcendent of exogenous constructionism, brings me to the second constructionism topic, namely that of endogenous constructivism.

\section{Endogenous constructivism}

Endogenous constructivism (Moshman 1982:372), especially in this context of the article, emphasises the individual nature of each learner's knowledge construction process and suggests that the role of the teacher (in a pedagogical contexts) should be to act as a facilitator in providing experiences that are likely to result in challenges to learners' existing models. If I say that the best way for pluralism (as an immanent construct), is to enhance sapiens of South Africa to apply themselves better in their pluralistic environment, as it then transcends these specific constructions through transcendence. How? I think for a start that pluralism in South Africa should be regarded as a border of transcendence

8. In the context of this article, cognition is a term referring to the mental processes involved in gaining knowledge and comprehension. These cognitive processes include thinking, knowing, remembering, judging and problem-solving. These are higher level functions of the brain and encompass language imagination. Therception higher and planning. See https.//Www.google.com/search?q=explain+cognitive+processes \&j1j15\&sourceid=chrome\&ie=UTF-8.

9.Please take note that in the context of this article, the term 'coded' could have been substituted with the term 'wired', for example, Homo sapiens are biologically coded or wired for transcendence (Van Rooyen 2018:2, footnote 3). in modus of our experienced (interpreted) experiences. Why? Because we live within a changing time and space (world) as a constant reality, the borders ${ }^{10}$ of transcendence will always be transcending borders and therefore also our pluralistic experiences in South Africa. I mean to say that there are different views of the borders of transcendence. There are cognitive borders (those that transcends our thoughts and reasoning) that exist, most of the time, next to each other in a specific time and space. As Van Rooyen (2018) suggests:

Moreover, the different views of transcendence borders can only be used in some independent modus to see which conviction is the dominant one. (p. 3)

Thus, also in the context of pluralism, the borders of transcendence have to do with epistemology, with a subjective understanding and with forces of power in a specific historical time. Pluralistic viewed, an experience of an imminent diversity into or onto the being of the transcendent does not constitute a transparent (what we desperately need in pluralism) understanding onto or into the being of the transcendent but rather a transparent perspective of sapiens' own understanding of themselves. ${ }^{11}$ In the context of endogenous constructivism, it is necessary to understand some - as all of them would be impossible - pluralistic views from a diversity consciousness as transcendence. As an example, in the natural science, certain developments created new spaces and opened up sapiens' understanding of the telos-transcendence as workings of $\operatorname{God}^{12}$ in a non-interventionists way-like transcendence and eschatology cannot be separated - pluralism has to accept and then reconceptualise transcendence. Why then is there this need to reconceptualise or convert the interpretation(s) of pluralistic immanence to pluralistic transcendence in our post-scientific and metaphysical time? Why then do I explicitly say that

10.Also take cognisance of the fact that the term "border" could also have been substituted, in the context of this article, with boundaries, post(s) or frontier(s). However, I am making use of the term 'border' as it better underlines the meaning of what I want to same time, I would like to state upfront: I speak n behalf of Therefore, I can only acksibility of a definite understanding of what transcend realm of a conscious interprete pluralistic mind. The crucial question in this regard is not if either transcendence or immanence is part of my interpreted pluralism structure of thought, but rather, how I as pluralistic-interpreted Homo sapien can use these especially important terms as functionalities to better the meaning, for the sake of myself, to enhance my understanding of myself in a pluralistic South Africa, and the world we live in.

11.Klaus Nürnberger (2011:198) remarks to this in a warning modus, albeit that this remark was said in the context on the origin of transcendence, as I think, we can also apply this to pluralism: 'Humans are so vulnerable and mortal. We are dependent on a system of knowledge that we belong, what roles is to play in our lives lived and our roles in the bigger picture of things. Transcendence therefore lives lived and our roles in the bigger picture of things. Transcendence therefore (specifically in the context of pluralism-JvR), has to do with those moments where every day human experiences are loaded with the faith and believe that there is eeper dimension to it all, and which can ascribe to the work of God. Therefore, especially, to take one example, the Christian believers cannot afford to try to negate the transcended origin of transcendence', and therefore, also into or onto pluralism that needs this as a validation, rather than a negation.

12.Regarding this specifically being said, at this stage and in context of pluralism. One must take note of Verhoef's (2016:1) remark: 'Transcendence is first typified as radical transcendence'. Therefore, in the endogenous constructivism (rooted in an organismic metaphor) emphasizing the coordination of previous organismic structures, it is of paramount importance that diversity becoming pluralism be experienced as radical transcendence. Meaning that it is a vertical type of transcendence where the absolute sapien is seen as (1) a very unique and totally distinct species regarding all others, and (2) clearly distinguished from the mundane (something that is very ordina (2) clearly distinguished from the mundane (som sapiens reality of life on this planet earth. This type of transcendence - pluralism transcends to what I am referring to hear, becomes problematic if all value of all sapiens in the world am re nihilism (life is meaningless) may arise should the possibility of the transcended be questioned. In philosophy, this type of questioning is especially prevalent in the onto-theological critique of metaphysics (Van Rooyen 2018:3). 
pluralistic transcendence is so important, and to further enhance this question, can pluralism transcendence be found, and if so, how and where? This brings me straight to the last constructivism, namely the dialectical constructivism.

\section{Dialectical constructivism}

The dialectical constructivism (Moshman 1985:322) is rooted in contextualistic metaphor and emphasises the construction of new structures out of organism and environment interactions, especially in this article's context has to do with radical reinterpretations of transcendent pluralism as the influence of the new cosmology ${ }^{13}$ (unique way of thinking of time and space), new biology and cognitive brain sciences, on philosophical pluralism, were (eventual) changing viewpoints into or onto transcendence. It is in this postmetaphysical as well as transcendental context that diversity tried to maintain its credibility through African pluralists, such as Nelson Mandela and a couple of his old guards; however, it did not cut the mustard. I think that the most profound reason for this has to do with a skewed view by many post-1994 African pluralists that they (the so-called post-colonial guard) regarded themselves and still do, as the so-called norm for the New Order or World then and now. This was hammered hard into and onto my own epistemological Gestimmheid ${ }^{14}$ when I made a remark to a North American academic at a conference in Athens (2019), when I spoke of Nelson Mandela just to be asked; who? Who is Nelson Mandela? And I am sad to say that this kind of arrogance still resonates here, specifically of our leaders, in contemporary South Africa today. However, there is always a positive, and there is a way forward. Let me explain:

In an article, Transcendent Pluralism: A Middle-Range Theory of Nonviolent Social Transformation Through Human and Ecological Dignity by Perry (2015), she stated the following:

Transcendent pluralism is a middle-range theory that focuses on the emergence of human dignity within relationships among diverse peoples through nonviolent social transformation. The theory proposes that contemporary social problems that negatively influence health are rooted in human and ecological devaluation and that healing is needed through the advance of dignity. (p. 1)

Thus, the theory of transcendent pluralism provides a framework for people seeking to advance dignity. This article provides an overview of the theory's development and components, and although the context of above-mentioned is within the framework of a medical-nursing hamlet, the idea resonates well on and in the South African contexts, as alike in the South African contexts, there is one thing, one characteristic, one powerful and profound eventuality here and now that South African sapiens long for in a deep

13.In the context of this pluralism transcendence, the new cosmology debate has explored numerous possibilities to accommodate sapiens actions on earth for over 2000 years now, without fully jeopardising the integrity of natural laws. I know and understand that this is open for debate as intelligent design and the problematic ugly head of reducing these natural laws through sapiens irresponsibility.

14.Gestimmtheit tote the substantial emotive heart-warming emotion Gemut, but then as a phycoexistential prejudice towards the phenomenon matter in the sensemaking procedures that canvas and regulate those very procedures. As Veldsman (2017:2), footnote 7 , hails it, ... the effective-cognitive dimension of human beings. acknowledgement of guilt: guilty that South African sapiens grew so intolerant with one another and therefore there are no space and time it seems, for dignity. South African sapiens are in dire need of this: firstly and foremost, within (into) ourselves and secondly, (onto) our marginalised hamlets. This is sadly true, for instance, that South Africa is the most violent country in the world regarding gender-based violence (GBV), and yet we call ourselves a Christian country (Veldsman 2020).

I, as a white South African born man can only shake my head in shame. This resonates why the urgent need for religious and cultural pluralism should be under serious discussion by our leaders, but it is not. There is nothing like the sight of an amputated spirit from these woman and children, there are no prosthetics for it.

\section{South Africa's way forward regarding pluralism, specifically into and onto of a new way of thinking about pluralism}

If and when South Africa hamlets mature after the initial victory over and against draconian laws pre-1994, it will have to endure hard soul searching. How? I think for a start, we have to accept that we as sapiens are not that special or even more unique in and amongst other sapiens of our planet earth. Although we have a very fine-tuned consciousness, our lack of integrity-based leadership is far from ideal. We have to confront legal pluralism with that of wish I have propagated here, a transcendent pluralism in as far as bring it under the attention of South African citizens and then even more, we will have to put our money where our mouths are, exactly through legal pluralism. This means that the following topics have to be debated vigorously (Mofokeng 2009):

1. The legal significance of extended families according to personal law.

2. Proof of the existence of a customary marriage.

3. The effect of affiliation: custody and guardianship.

4. Polygamy.

5. The doctrine of religious entanglement.

6. Legal pluralism and personal family law.

7. Forms of religious and customary marriages. (p. 1)

The only constant reliability since post-1994 was our slivery victories in the constitutional courts. So far, I think that we have set some standards in Africa regarding this. I just need to think of only three positive ones (as there are many more from 1995 till present) those are as follows:

1. S v Makwanyane and Another (CCT3/94) (1995) ZACC 3; 1995 (6) BCLR 665; 1995 (3) SA 391; (1996) 2 CHRLD 164; 1995 (2) SACR 1 (06 June 1995). S v Makwanyane and Another was a landmark 1995 judgement of the Constitutional Court of South Africa. It established that capital punishment was inconsistent with the commitment to human rights expressed in the Interim Constitution (SAFLII 1995a). 
2. S v Zuma and Others (CCT5/94) (1995) ZACC 1; 1995 (2) SA 642; 1995 (4) BCLR 401 (SA); 1995 (1) SACR 568; (1996) 2 CHRLD 244 (05 April 1995). S v Zuma and Others was the first case decided by the Constitutional Court of South Africa after it was established in 1995 (SAFLII 1995b).

3. S v Mamabolo (CCT 44/00) (2001) ZACC 17; 2001 (3) SA 409 (CC); 2001 (5) BCLR 449 (CC) (11 April 2001). S v Mamabolo is a case in which the Constitutional Court of South Africa dealt with the relationship between contempt of court and freedom of speech (SAFLII 2001).

\section{To summarise}

Thus, with the aim of the article that resonates under the heading contribution, in the beginning of this article, it was shown that a coherent meta-theory was presented in specifying the the boundary conditions in each root metaphor whereby I promoted that a better constructive pluralism will be applicable. I made use of three root metaphors, namely (1) exogenous constructivism (rooted in a mechanistic metaphor) emphasising the reconstruction of structures preformed in the environment; (2) endogenous constructivism (rooted in an organismic metaphor) emphasising the coordination of previous organismic structures and (3) dialectical constructivism (rooted in a contextualistic metaphor) emphasising the construction of new structures out of organism and environmental interaction. From there, I then discussed what diversity and pluralism in the South African context is by making use of five subheadings, namely (1) that diversity in South Africa is not the exact fact or facet of pluralism alone; yet, it is an active engagement with that diversity; (2) that dissimilarities are somewhat not just the mere sufferance of dissimilarities as it necessitates understanding of these differences and although tolerance is important, it can be a fallacious probity by itself, conceivably even capacities in the road of promise; (3) that pluralism is not at all just simply relativism, and therefore, it does make room for real and different religious commitments; (4) that pluralism in South Africa is plainly located on the simplistic terrain laws regarding the constitution, and within the vigorous confrontation, the pluralistic hamlets are not allowed on consummating the legality on achievable consciousness and belief, rather than consummating something far more achievable, transcendence of immanent constructions through legal pluralism and (5) that pluralism obligates the sustenance of productive discourses to unveil both simplistic interpretations and real dissimilarities. Not all at the table will respond positively, what is vitally important is that everyone is at the table.

I, therefore, would categorically state that these abovementioned pluralisms as tools are a reminiscence and a jubilee of the efforts made by South African sapiens through diversity onto or into a South African pluralism to enable the religious hamlet to think, and share, in their epistemological foundational point of departure that will enhance their religious and cultural experiences as sapiens in their respected time and space. This pluralistic approach of orientation, I hope, will empower sapiens of South Africa in their respective hamlets to define, articulate and designate progress of their own epistemological and ontological vantage points wherefrom their individual, coherent and contextual ways of thinking, acting and projecting life in a positive modus by emphasising the reconstructions of their performance in their environment, by coordinating their previous organismic structures, and for now, their organismic and environmental new structures, with a definitive demeanor.

\section{Conclusion}

Notwithstanding this, on a more personal and positive note, South African sapiens do have the resources such as cognitive as well as affective faculties amongst themselves precisely because of diversity and therefore pluralist South African unique contexts and positive mentality (albeit not always), to make it happen, to make it work. If the South African sapiens in their respective hamlets transcend their immanent religious and cultural beliefs from (1) an exogenous constructivism (rooted in a mechanistic metaphor) emphasising the reconstruction of structures preformed in the environment; (2) endogenous constructivism (rooted in an organismic metaphor) emphasising the coordination of previous organismic structures and (3) dialectical constructivism (rooted in a contextualistic metaphor) emphasising the construction of new structures out of organism and environmental interaction, a better new South African hamlet can be created. However, even more mortally important, with dignity, it will defiantly lead eventually to a better South Africa. To quote the (in) famous Nelson Mandela (1994):

When a man is denied the right to live the life he believes in, he has no choice but to become an outlaw. (p. 18)

\section{Acknowledgements Competing interests}

The author declares that he has no financial or personal relationships that may have inappropriately influenced him in writing this article.

\section{Author's contributions}

J.A.v.R. is the sole author of this study.

\section{Ethical considerations}

This article followed all ethical standards for research without direct contact with human or animal subjects.

\section{Funding information}

This research received no specific grant from any funding agency in the public, commercial or not-for-profit sectors. 


\section{Data availability}

Data sharing is not applicable to this article as no new data were created or analysed in this study.

\section{Disclaimer}

The views and opinions expressed in this article are those of the author and do not necessarily reflect the official policy or position of any affiliated agency of the author.

\section{References}

Cognitive Processes, 2020, viewed 24 October 2020, from https://www.google.com/ search?q=explain+cognitive+processes\& $0 q=$ explain + cognitive + prosesses\&aqs $=c$ hrome.1.69i57j0i13i457j0i8i13i3012.11838j1j15\&sourceid=chrome\&ie=UTF-8.

Dialectic Constructivism, 2020, viewed 26 September 2020, from https://www. google.com/search?sxsrf=ALeKk03ZA877VNJyDN0sbSMPXTApdG2BLw\%3A1603 $775597380 \&$ ei=bayXX53fFt-T1fAP47-B6A0\& $q=$ what+is+a+dialectical+constructiv ism\& $\&=$ hat+ista+diatical

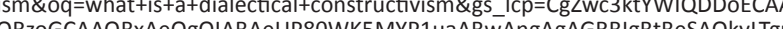
QRzoGCAAQBXAeOgQIABAeUP80WK5MYP1uaABwAngAgAGRBIgBtBeSAQkyLTgu MS4wLjGYAQCgAQGqAQdnd3Mtd2I6yAEGwAEB \& sclient=psy-ab\&ved=
OahUKEwjdyZ WgdTsAhXfSRUIHeNfANOQ4dUDCA0.

Exogenous Constructivism, 2020, viewed 24 October 2020, from https://www.igiglobal.com/dictionary/exogenous-constructivism/86876.

Long, C.H., 2016, Creation myth, Encyclopædia Britannica, Inc., viewed 06 May 2020, from https://www.britannica.com/topic/creation-myth

Mandela, N., 1994, Long walk of freedom, Little Brown \& Co., New York, NY, viewed 27 October 2020, from https://en.wikipedia.org/wiki/Long_Walk_to_Freedom.

Mofokeng, L.L., 2009, Legal pluralism in South Africa - Aspects of African customary, Muslim, and Hindu family law, Van Schiak Publishers, Pretoria, viewed 27 Octobe 2020, from https://www.vanschaiknet.com/book/view/177\#: :text=South\%20 Africa $\% 20$ is $\% 20$ a $\% 20$ pluralistic, any $\% 20$ form $\% 20$ of $\% 20$ unfair $\% 20$ discrimination.
Moshman, D., 1982, 'Exogenous, endogenous, and dialectical constructivism' Developmental Review 2(4), 371-384. https://doi.org/10.1016/0273-2297(82) 90019-3

Nürnberger, K., 2011, Regaining sanity for the earth: Why science needs best faith to be responsible, why faith needs best science to be credible, Cluster Publications, Pietermaritzburg.

Perry, D.J., 2015, 'Transcendent pluralism: A middle-range theory of nonviolent social transformation through human and ecological dignity', ANS Advances in Nursing Science 38(4), 317-329. https://doi.org/10.1097/ans.0000000000000086

Southern African Legal Information Institute (SAFLII), 1995a, S v Makwanyane and Another (CCT3/94) [1995] ZACC 3; 1995 (6) BCLR 665; 1995 (3) SA 391; [1996] 2 CHRLD 164; 1995 (2) SACR 1 (6 June 1995), viewed 30 September 2020, from http://www.saflii.org/za/cases/ZACC/1995/3.html.

Southern African Legal Information Institute (SAFLII), 2001, Sv Mamabolo (CCT 44/00) [2001] ZACC 17; 2001 (3) SA 409 (CC); 2001 (5) BCLR 449 (CC) (11 April 2001) viewed 30 September 2020, from http://www.saflii.org/za/cases/ZACC/2001/17. html.

Southern African Legal Information Institute (SAFLII), 1995b, $S \vee$ Zuma and Others (CCT5/94) [1995] ZACC 1; 1995 (2) SA 642; 1995 (4) BCLR 401 (SA); 1995 (1) SACR 568; [1996] 2 CHRLD 244 (5 April 1995), viewed 30 September 2020, from http:// www.saflii.org/za/cases/ZACC/1995/1.html.

Van Rooyen, J.A., 2018, 'Transcendence, immanence, and religious experiences in a post-transcendence era', Verbum et Ecclesia 39(1), a1838. https://doi.org/ 10.4102/ve.v39i1.1838

Van Rooyen, J.A., 2020, 'Cosmogonic or creation myths: A mythical, philosophical and theological interpretation of the diverse cosmogonic myths: In conversation with Charles Long', HTS Teologiese Studies/Theological Studies 76(1), a5853. https:// doi.org/10.4102/hts.v76i1.5853

Veldsman, D.P., 2017, 'The place of metaphysics in the science-religion discourse', HTS Teologiese Studies/Theological Studies 73(3), a4655. https://doi.org/10.4102/hts. v73i3.4655

Veldsman, D.P., 2020, Presentation 15 September 2020, viewed 30 September 2020, from https://us02web.zoom.us/rec/share/60_FQ94j8As4gN-7ATDnDItjfkO5vBO2 cYc2e4wokVzjAINyvm Mbj95nxGHgTwV_MFPVUskMFpJHORPu.Password RiigW8U!.

Verhoef, A.H., 2016, 'Embodied religions radicalization of immanence and the consequent question of transcendence', Acta Academia 24(4), 173-194. 